\title{
ANNOUNCEMENTS
}

\section{DECHBER METTNGS}

Dec. 6. Today's Profit Opportunities in Biotechnology. Houston, TX. (Also Jan. 29 in London, and Jan. 31 in Basel, Switzerland) Info: Consulting Resources Corp., 6 Northbrook Park, Lexington, MA. 02173.

Dec. 9-13. Chemical Specialties Manufacturers Association Annual Meeting. Miami Beach, FL. Info: CSMA, 1001 Connecticut Ave., NW, Washington, D.C. 20036

Dec. 10-12. 4th International Symposium on High Performance Liquid Chromatography of Proteins, Peptides, and Polynucleotides. Baltimore, MD. Info: Shirley Schlessinger, Symposium Manager, 400 East Randolph St., Chicago, IL, 60601

\section{MUUARY METTIGS}

Jan. 26-Feb. 2. UCLA Symposium on Monoclonal Antibodies and Cancer Therapy. Park City, UT. Info: Betty Handy, Program Coordinator, UCI.A Symposia, Molecular Biology Institute, University of California, Los Angeles, CA 90024

Jan. 28-Feb. 1. 9th Annual Symposium on Energy from Biomass and Wastes. Lake Bueno Vista, FL. Info: Institute of Gas Technology, 3424 South State St., Chicago, IL 60616

\section{FanUAR Matlios}

Feb. 3-6. 5th Annual Congress for Recombinant DNA Research and 4th Annual Congress for Hybridoma Research. San Francisco, CA. Info: Edward R. Ruffing, Scherago Associates, 1515 Broadway, New York, NY 10036

Feb. 7-8. 2nd Annual Congress on Automation, Scale-Up, and the Economics of Biological Process Engineering. San Francisco, CA. Info: See for Feb. 3-6.

\section{Mrä Matines}

March 3-8. American Society for Microbiology Annual Meeting. Las Vegas, NV. Info: Richard A. Bray, Meetings Dept., ASM, 1913 I St., NW, Washington, D.C. 20006

\section{Exectime chaness}

Schering-Plough (Madison, NJ) appointed J. Allan Waitz president and chief executive officer of DNAX Research Institute and vice presidentbiotechnology for Schering's pharma- ceutical research division. Schering also named Steven C. Chellevold senior director-operations for its animal health division, Zachary Finkelberg senior director-Schering I aboratories medical research, in the pharmaceutical research division, and Colin Dalton director-business development, pharmaceutical operations.

AgriTech Systems (Portland, ME) appointed Erwin F. Workman, Jr. vice president for research, development, and operations, and Chester $\mathrm{L}$. Crum vice president for marketing. Workman leaves Abbott Laboratories; Crum had been with American Cyanamid.

Plant Genetics (Davis, CA) appointed Zachary S. Wochok president and chief executive officer. He was also named a director.

International Plant Research Institute (San Carlos, CA) announced that W. Hsiao-tsu Loh and Charles R. Brown have joined its scientific staff.
Calgene (Davis, CA), which is trying to change its corporate image, appointed Nanette Newell director of research administration. She had served as project director for the Office of Technology Assessment's recent report on commercial biotechnology.

Chem Systems Research (Fairfield, $\mathrm{NJ}$ ) appointed Sol J. Barer vice president. He will continue to direct Chem Systems' biotechnology efforts.

Pharmacia A.B. (Uppsala, Sweden) appointed Gunnar Wessman chairman of the board. Erik Danielsson succeeds Wessman as president and chief executive officer. Also, Nobel laureate Bengt Samuelsson was named vice chairman.

Cytogen Corp. (Princeton, NJ) elected Lewis Thomas to its board of directors. Thomas, who is a professor at the State University of New York at Stony Brook, will also serve as a member of Cytogen's scientific advisory board.

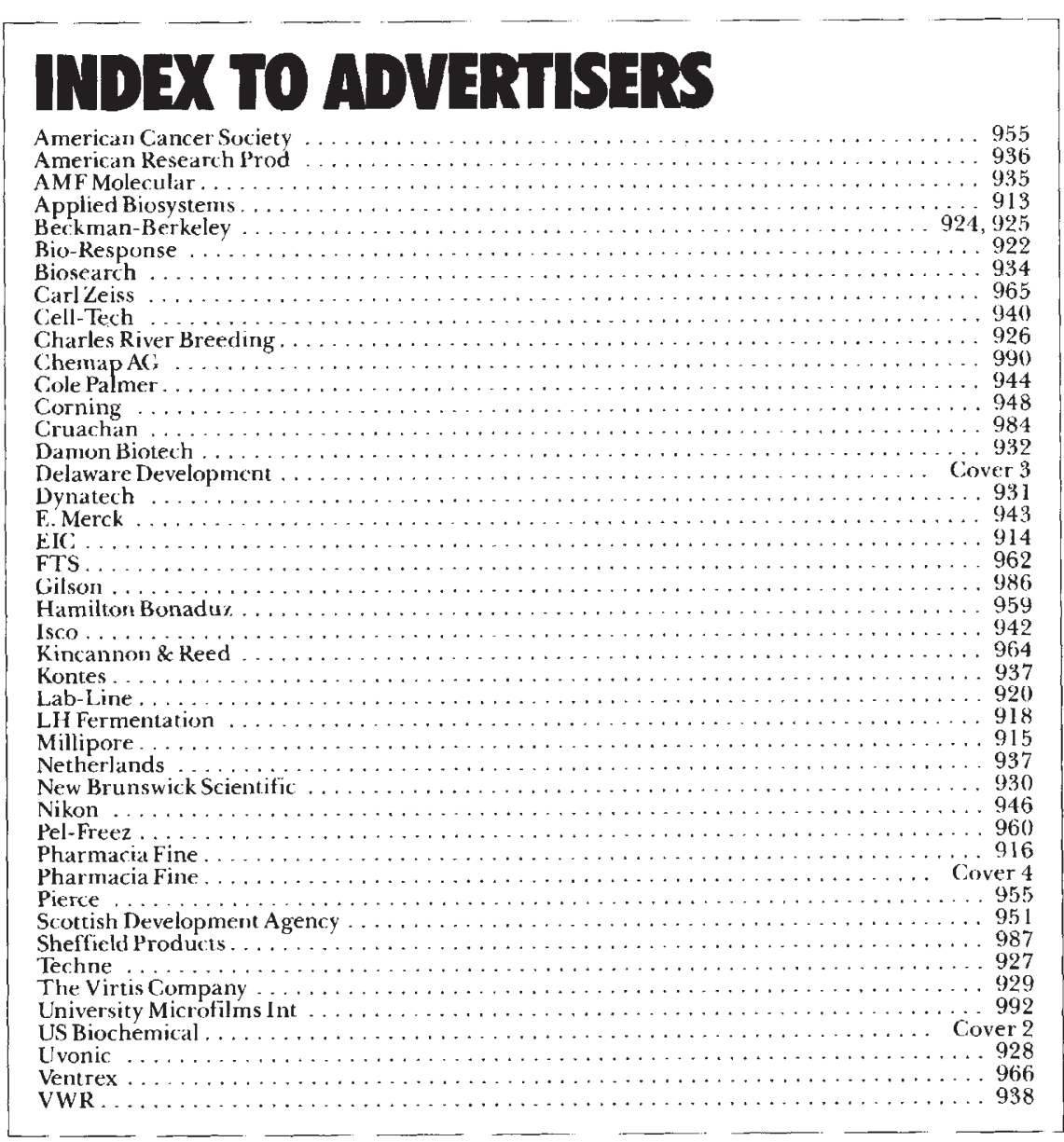

